\title{
Nonverbal Communication in the Concept of Javanese Opera Film Artistic Arrangement
}

\author{
Heri Nugroho \\ Universitas Ahmad Dahlan \\ Email: herinug.kidul@gmail.com \\ *corresponding author
}

Keywords:
Communication, Film, Nonverbal

\begin{abstract}
The film is one of the communication media used to convey information from its creator to its audience. The film is one of the media communications. The event for phenomenon becomes evidence that when watching a film, there is information conveyed to the audience, both the likes and dislikes. This research aims to find a solution to the communication problems in the "Opera Jawa" film. As a communication medium, the film is capable of providing education. This research was conducted using qualitative research methods to obtain factual data to explain and explicate coherently so that it is accessible in the delivery process. After an analysis of the study of nonverbal communication on the Opera Javanese film, it can be concluded that art as a form of aesthetic value and communication media means to communicate through beauty with a series of information packaged through visual language, making it richer and more diverse in how to communicate.
\end{abstract}

Copyright (C) 2021 Channel Jurnal Komunikasi. All right reserved.

\section{INTRODUCTION}

In 1900, on December 5, the first cinema opened in Indonesia, namely in Batavia or now Jakarta. The first film (live image) shown in cinemas in Batavia was a documentary about the journey of Queen Olanda and King Hendrik in The Hague. Since this historical event became the beginning of Indonesia's introduction to films with a long history of Indonesian cinema, Indonesian people are very familiar with various genres of film and cinema. In 1900-1940 film was a multiethnic spectacle. At the end of the 19th century, the Dutch East Indies had a population of various ethnicities consisting of natives, Europeans, and Chinese. The public became familiar with traditional spectacles such as wayang orang and Chinese puppets to modern ones such as comedy Stamboul, forming a new entity, namely the audience (Nunus, 2016).

The film is one of the communication media used to convey information from its creator to the audience. The film has become a popular spectacle in Indonesia, both for entertainment and appreciation media and learning media for film academics. The film is a mass media, which is not only to communicate personally but also to disseminate information widely and can be consumed en masse by the public, not just for personal use (Bungin, 2006).

Regarding this statement, the film has a role in disseminating mass information through audio-visual media. With audio and visual facilities, films can only be watched using modern electronic devices that provide the best quality in presenting films to the audience. furthermore, the film also gives the audiences a good or bad movie after they watch a movie. So, these events or phenomena are evidence of information conveyed to the audience when watching a film, whether it is information they like or do not like.

In a film, there will always be a series of storylines that the audience will enjoy through audio-visual packaging. In the story, the film's creator communicates many messages and information to the audience. In addition to story/narrative elements, films also have cinematic elements. These two elements interact and are continuing to form a film (Pratista, 2017). One part of the cinematic element is the mise en scene, which is everything in front of the camera caught by the camera and presented in the frame. The film's narrative is a series of continuous images that change and describe events from various points of view (Pracihara, 2014). 
Artistic arrangement Includes having an essential role in the image's appearance in all the elements incorporated in the mise en scene, namely settings, costumes, makeup, effects, properties how an artistic stylist can translate the scenario into a visual design that measures the film's success. In conveying information, the failure of the artistic stylist is one of the main factors in the failure to convey communication in the film, how not, what will be made by the artistic stylist is everything that will appear on the screen of the film, the information includes all the information that will be conveyed to the audience, Among other things, the place and time of occurrence of events in the scene, symbols that reinforce events, color and composition controlling the psychology of the audience, the culture presented, and so on.

Opera Jawa is not like classic films in general. The audience can easily sit in front of the screen and follow and understand the presented storyline while enjoying popcorn on their laps. Without being disturbed by what is presented in the film, they are watching. The Javanese Opera film is a dance film that tells the puppet story of Rama and Sinta. For the visual of the film Nanang Rakhmat Hidayat as art director, designed the concept so that the visuals in this film are closely related to unconventional works of art filled with symbols and meaning reasoning.

Kris Budiman, in the foreword of his book entitled 'Ajang Perteruan Manusia,' said that the Java Opera film is tiresome and sleepy. Several relatives and students who have come to the house later watching the film Opera Jawa said that this film is a film that confuses the audience. They do not understand at all what is being presented in the film.

In studying visual semiotics and fine arts disciplines, the film has a rich visual meaning, for example, artistic arrangement. Nanang Rakhmad Hidayat certainly plays an essential role in this film by occupying the position of an Artistic stylist. The three-dimensional, symbolic, and segmented visuals throughout the film are presented as art and nonverbal communication. This study is essential, especially for designers and creators of visual communication media. So that they are also effective in conveying messages to audiences and all film audiences, especially communication science academics, so that they gain insight into understandings of visual film language, it will always grow.

\section{A. Film}

Film language is a combination of sound language and image language. Filmmakers offer a solution through their films, hoping that the audience will well receive them. Through their mental and cultural experiences, the audience plays an active role, consciously or unconsciously, to understand a film as a whole, which is greatly influenced by the person's understanding of a film's narrative and cinematic aspects (Pratista, 2017).

Fiction films are different from documentaries. The plot binds fiction films. From the side of the story, fiction films often use fictional stories outside of actual events and have a scene concept that has been designed from the start. The law of causality also binds the structure of the film's story. Stories also have protagonists and antagonists, problems and conflicts, closures, and clear story development patterns. In terms of production, fiction films are relatively more complex than the other two types of films.

A drama must have a weapon that can predict whether the film that will be made can seize the audience. Therefore, the drama quality of fiction films is influenced by the following elements:

1. Conflict, in fiction films conflict, is an important thing. After building the characters in the story, what problems must be created? The closer the problem is to the audience's reality, the closer the audience is involved in it.

2. Likes, viewers will choose a program that features a captivating main character with a personality that can steal the audience's attention.

3. Consistent, the film must have a consistent story between the characters and the characters in the story.

4. Duration: A film must have time stability if shown simultaneously, even though the theme and story are different.

5. Energy, Fiction films must have the power to prevent the audience from diverting their attention to other things. In this case, it emphasizes the speed of the story and the passion for the story by presenting images that the audience cannot leave (Morissan, 2018).

\section{B. Film Artistic Design}

In creating a work of art, it will be based on two main things. The first is related to the aesthetic concept of the work, namely a process of the creator's imagination in translating all the material into a work of art. The second is related to the technical method used in realizing the work art (Nugroho, 2020). The process is done in an observant and coherent manner to discover a work of art that has the power to show its value, not to mention a work of film art. Film strength can be exercised in various aspects. One of them is the power of artistic arrangement to further bring the narrative elements to life visually.

The Art Director or Art Director contributes an essential background in the making of a story film. In the artistic arrangement, it cannot be separated from the performance of a Production Designer. The Production Designer contributes concepts, ideas, styles, and backgrounds vital in each type of story filmmaking. Production Designer concentrates entirely on a picture of overall artistic composition to interpret a script and a director's vision. The creative stylist has an essential role in every information presented in each frame that has a big concept. The structure creates a composition. Namely, 
anything that has been arranged for the excellent presentation to form a suitable arrangement in a frame. The design also plays an essential role in the audience's emotions, which happen directly or indirectly. The composition can attract the audience's attention at the desired point (Pungkiawan, 2014).

Based on William Cameron Menzies,

"Art Director was responsible for the visual look of the film. It is now recommended that the person in charge of what used to be known as "art direction" be assigned the title "Production Designer" (Whitehead, 2002).

Based on these conclusions, the Art director is an assistant to the Executive Production Designer in the film both in the field and on the telephone and is responsible for supplier agreements (artistic needs) and logistics to procure all materials in the set. If there is no Production Designer in a film, the Art Director will be responsible for designing a film. One position as a Production Designer is an honor.

In other different from story film production in Indonesia, there is still very little of a Production House (PH) using the performance of a Production Designer. In Indonesia, the Art Director then has a dual role as a Production Designer, the leading creator in a story film, whether shot entirely on location or in a studio. Every shot in a story film must be carefully planned.

The Artistic Stylist or Art Director conveys information about the meaning of the story through a symbolic approach, one of which is a form of nonverbal communication that will be transferred to the audience through the visual language of the film. A symbol is a symbol that represents an idea (Sobur, 2006). Herusatoto mentions that the symbol comes from the word "symbolos," a sign or feature that tells someone something. Herusatoto added that a symbol could be defined as a form that marks something other than the embodiment of the symbolic form itself (Sobur, 2017).

Visuals/images are imitations of animate and inanimate objects made by painting, while images result from drawing. Images are images, sculptures, impressions, and shadows, while image (Ing.) is an inner/mental impression or a visual image generated from object figures in works of art (Rusli, 2018). In Charles Sanders Pierce's theory, the signs in the picture can be seen from the types of signs classified in semiotics. Among them: icons, indexes, and symbols (Nöth, 1995). A sign, or representation, is a symbol that replaces something for someone in some respect or capacity $\square$ a symbol, a property that builds character. In every form of a story, a sign is something concrete (a particular object, story, person, sound, event, or place) that represents or symbolizes a complex of ideas, attitudes, or feelings to acquire a more significant meaning than stored in itself. According to Sumbo Tinarbuko in his book Semiotics of Visual Communication, a symbol is a sign based on convection, rules, or mutually agreed agreements. The audience can understand the new symbol by understanding the previously agreed meaning (Tinarbuko, 2008).

A systematic theory of art is most widely read in the book Philosophy in a New Key by a famous philosopher, Suzanne K Langer, expressing the main idea that art is an expressive form or an icon symbol of emotion. For Langger, there are two kinds of symbol differences. The first is a discursive symbol, and the second is a presentational symbol.

A discursive symbol is a symbol captured using reason or intellect. Therefore, it is also called a symbol of reason. The delivery of what will be disclosed takes place sequentially, not spontaneously. Analyze questions with modern symbols. What is included in the discussion symbol is language, both everyday language (the language of ordinary thought), the language of science (the language of scientific knowledge), or the language of philosophy (the language of Philosophical Thought). Discursive symbols contain a structure built by words according to the laws of grammar and syntax. Ignoring the law causes the sentence to lose its meaning or cannot be understood. There is a blur of meaning.

While the presentational symbol is a symbol whose expression does not require the intellect, it spontaneously presents what is developed. The presentational symbol can stand alone as a potent symbol, meaning that it is not built from construction or in stages but is a complete and unified strength. Symbols like this are what we encounter in nature and human creations, namely dance, painting, ornament, and so on. Its meaning is not captured by logic but by direct intuition. The dance or painting is captured only through the meaning between the symbol elements in the overall structure. As a unified whole, representational form speaks directly to the human senses. Representation is an essential part of producing meaning or meaning that we exchange with other members (Fauziah et al., 2020).

\section{METHODS}

This type of research is qualitative research. The study is allocated to self-activity as an observer. Qualitative research includes the use and collection of various empirical data used, namely personal experiences, interviews, observations, and interactions, which can describe various routine and difficult moments and meanings of the subjects being faced in life (Wenerda, 2020).

This research was carried out using descriptive qualitative research methods to obtain factual data to explain so that it was easy to deliver. Isaac \& Michael demonstrated that the descriptive approach systematically and accurately explains facts, characteristics, areas, or areas of a particular population (Rakhmat, J., \& Surjaman, 2012). In this study, it is essential to use this method to explain what is being studied. 


\section{RESULT AND DISCUSSION}

The film cannot be separated from cinematography, even though it has become the most identical characteristic for the film medium. Cinematography is formed from the word kinema (Greek), meaning movement. Graphene is interpreted freely by painting, recording (Suprihono, 2019). Becoming a film character shown in a film is different from a stage performance or art exhibition. However, the film is a moving picture or performance resulting from a camera recording process that is presented again using a device so that the film has its character compared to other mediums and how to enjoy or watch it.

Being a spectator or in the aspect of communication is as a communicant as if passive. He will only accept any information conveyed by the communicator. More than receiving messages, a communicant is also required to be active, at least able to understand and understand what messages he has received. What has been understood will be continued in responding to the following process. The process of understanding and understanding the message received is not as easy as just accepting it without knowledge and understanding. For example, a person who does not master English will have difficulty understanding the message he receives in English.

The Javanese Opera film, like what was said before, in essence, represents the love story of Rama and Sinta. The story is packaged in a film format that communicates very strongly using nonverbal visual language. Of course, it is not easy to make agreements on new codes or symbols to establish good communication. When we talk about symbols, it means that we are in dialogue with the study of semiotics. The study of semiotics, in general, is a study of signs, which are then associated with all the roles of these signs in social life (Wibowo, 2019).

In this study, the presentation of several samples presented in the artistic arrangement of the Opera Jawa film will be given, which is then intended as a look and mood builder and forming symbols that tell stories through visuals. In it, films can construct social values and can be used as a medium to convey ideology (Muafa \& Junaedi, 2020). Every film creator is an artist or creator who always has a unique way of conveying all the ideas he has and deemed necessary and exciting to be conveyed in that way. Opera Jawa has a unique style in delivering its message.

With this form and style of narrative, the data has shown that most of the audience it hard to understand the content and meaning of the symbols/metaphors displayed through visuals. Especially in the concept of artistic arrangements, such as the appearance of property- unique properties and costumes that make the audience have to watch this film repeatedly to understand the meaning of these symbols.

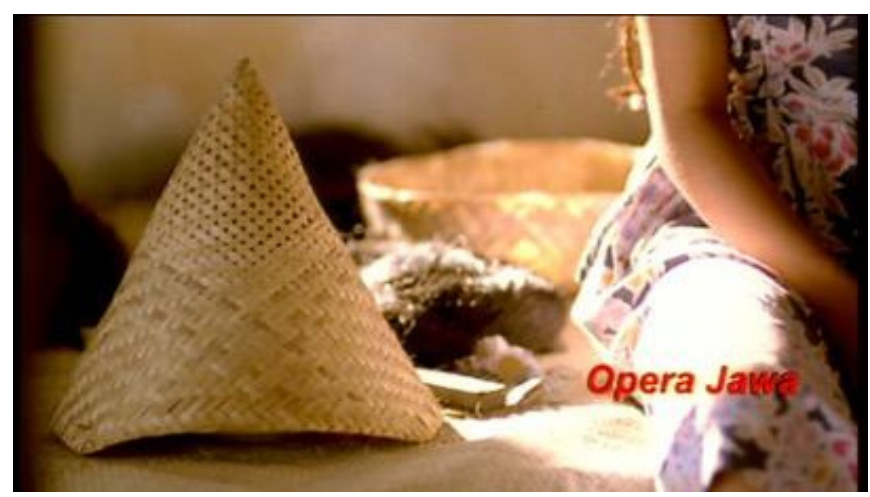

Figure 1. The creature with the head of a rice steamer in the Javanese opera film

In the early scene 2, the visual of this film presents a scene of Siti's fear of the presence of a long-bodied creature with a pointy head, which is seen as a rice steamer chasing and trying to attack her crotch, which in the end becomes tame after Siti holds her head. This scene closes with Siti taking the steamer and putting it as a serving hood. This scene is presented precisely after scenes of Siti and her husband Setyo pledging allegiance to each other. Kris Budiman said this creature represents Ludiro's male passion for Siti (Budiman, 2016). The steamed rice appears in several other scenes when the scene is a scene that informs about Ludiro's male passion for Siti. In this film, Ludiro is the antagonist for the harmony of loyalty between Setyo and Siti. 


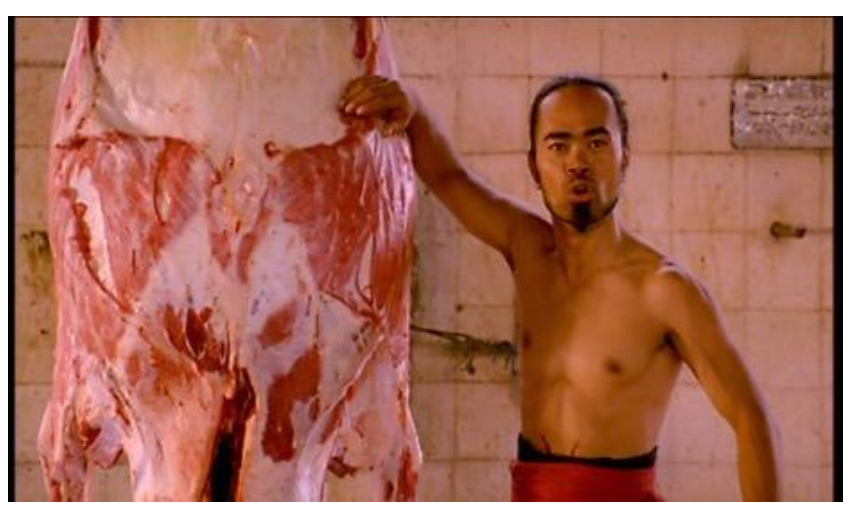

Figure 2. Ludiro in a slaughter room

In the figure above is the scene of the introduction of Ludiro's character. In this scene, Ludiro is seen in a cattle slaughter room where he introduces himself. The setting shown with the meat property that forms a slaughter room in this introduction scene has the power to build Ludiro's character. Butcher is synonymous with violence. Butchering means killing. Conflict can be built from anywhere, one of which is human existence (Sadewa, 2019). Ludiro's existence as a source of conflict in this film's story is built as a character identical to violence, and what he wants must be achieved by forcing his will to use violence. Power is depicted at the end of the scene by holding a cow's head, and several headshaped installations representing power are placed on the floor where its position under the Ludiro is standing. This composition illustrates how strong Ludiro is in power so that no one can resist what has become his wish.

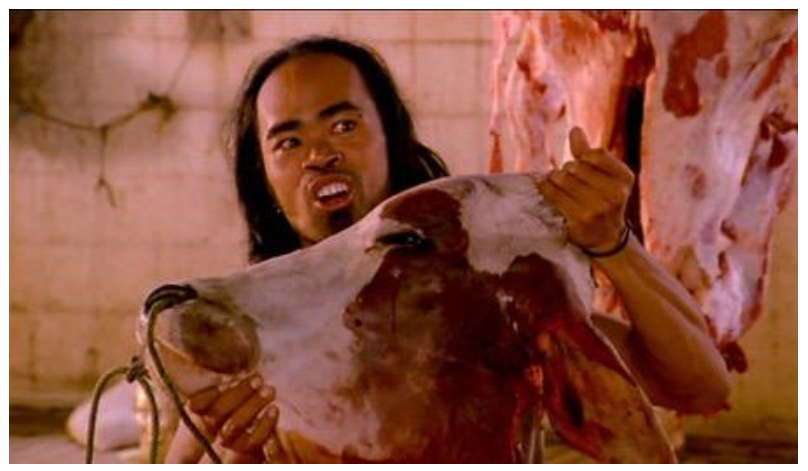

Figure 3. Ludiro in a slaughter room, dancing on a cow's head with some head installations.

One more uniqueness of the Javanese Opera film, in general, the concept of artistic arrangement in the film is oriented to an existing scenario, so what an artistic designer will do is the result of a scenario analysis which is then broken down to find out all the needs then technically the property will be procured. And other elements. In the film Opera Jawa, the works of art artists in several scenes are a priority. Nanang Rahmat Hidayat, Art Director of Opera Jawa, said that some scenes were created because there was a property that used to be the idea to create a scene. The properties in question are works of art from great artists created long before the Javanese Opera production process was carried out, one of which is the wax installation in the shape of a human head in the figure above. 


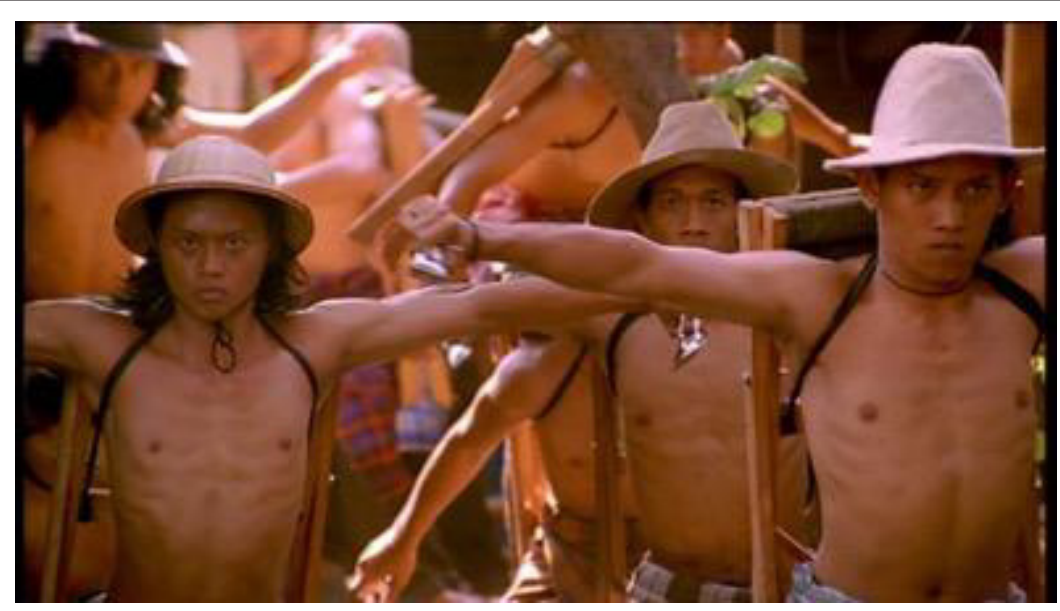

Figure 4. Ludiro's men prepare to carry out a massacre in the market

Strengthening the character of Ludiro's antagonist, there is a performance syntagma depicted through a colossal market scene in another scene. A group of Ludiro's men who carried out terror in a market carried out destruction and massacres without the slightest resistance. Ludiro's power and violence become vital in this scene. Statues or dolls are hung. The average viewer will say that nothing more than a hanging doll or statue when watching the visuals presented in scene 11. In Kris Budiman's discussion, it turns out that it is not just that. There is a specific meaning and purpose in the scene. The statue or doll that is hung is a visualization of the body of the victim of the massacre carried out by Ludiro's men. This statue is essential to convey its meaning in the development of the antagonist Ludiro.

From the several visual examples of Opera Jawa in the images of the Opera Jawa film clips, examples are taken from the section where the artistic emphasis is placed on presenting symbols as a form of nonverbal communication. As already discussed, the information contained in the symbols presented through the artistic arrangement of the Opera Jawa film is extensive and essential to convey to the audience.

\section{CONCLUSION}

After analyzing the study of nonverbal communication in the Opera Jawa film, it can be concluded that art as a form of aesthetic value and a medium of communication means communicating through beauty with a series of information packaged through visual language, making it richer and more diverse in how to communicate. In art, novelty is always demanded as well as art for communication purposes. Creators should always have a novelty that is continuously offered in communicating using art media, which means that an art creator must continuously create new languages in art as a communication medium. However, the law of communication demands that the message's delivery measures the effectiveness of communicating, which means that the languages used in communicating are the same language understood by the communicator and the communicant.

In art communication, especially visual arts, iconology is undoubtedly very important to use in reading works. Iconology is a way of understanding works of art by determining the meaning of their content by revealing the meanings contained in it (Wibowo \& Ayu, 2020). Being a spectator is being a communicant. When deciding to become a movie audience means being ready to receive any information about what will be conveyed through the film. Capability is something that is very strongly related to knowledge and intelligence. People are easier to catch things in mind when they have a good grasp of intelligence, and being able to be on the same topic for what they receive requires sufficient insight and experience to at least know what they are receiving. In the Javanese Opera film, many things must be fulfilled to enter the audience segment. In the aspect of the romance story of Rama and Sinta, the main menu is represented through the characters Setyo and Siti to make it easier to follow the plot. The audience at least has the capital of insight.

\section{REFERENCES}

[1] Budiman, K. (2016). Ajang Perseteruan Manusia, Sebuah Kajian Semiotik Atas Opera Jawa Garin Nugroho. Penerbit Ombak.

[2] Bungin, B. (2006). Sosiologi komunikasi : Teori, Paradigma, dan Diskursus Teknologi Komunikasi di Masyarakat. Kencana Prenada Media Group Indiana University Press.

[3] Fauziah, A. N., Rohman, A. A., Monida, W. O. G., \& Hariyanti, N. (2020). Wayang Ukur Sebagai Media Representasi Indonesia. Channel: Jurnal Komunikasi, 1(1), 43-50. 
[4] Morissan. (2018). Manajemen Media Penyiaran: Strategi Mengelola Radio \& Televisi Ed. Prenada Media.

[5] Muafa, K. A., \& Junaedi, F. (2020). Model Manajemen Produksi Film Dokumenter Bulu Mata Karya Tonny Trimarsanto. Channel Jurnal Komunikasi.

[6] Nöth, W. (1995). Handbook of Semiotics. Indiana University Press.

[7] Nugroho, H. (2020). “ASAT” Seni Video instalasi. Citra Dirga : Jurnal Desain Komunikasi Visual Dan Intermedia.

[8] Nunus, S. (2016). Seabad Sensoer Gambar Idoep Di Nusantara 1916-2016. Pusat Pengembangan perfilman kementerian dan kebudayaan.

[9] Pracihara, M. M. (2014). Membangun Look dan Mood Melalui Warna Pada Videografi Film Televisi "PANCER." Perigi Journal Of Art and Cultural Interdisciplinery Studies.

[10] Pratista, H. (2017). Memahami Film Edisi 2 (2nd ed). Homerian Pustaka.

[11] Pungkiawan, P. R. (2014). Visualisasi Konflik Batin menggunakan Keseimbangan Dalam Komposisi Drama Televisi "SELIBAT." Perigi Journal Of Art and Cultural Interdisciplinery Studies.

[12] Rakhmat, J., \& Surjaman, T. (2012). Metode penelitian komunikasi: dilengkapi contoh analisis statistik. Remaja Rosdakarya.

[13] Rusli, E. (2018). Citra dan Tanda Malioboro dalam Konstruksi Fotografi. Rekam Jurnal Fotografi, Televisi, Dan Animasi.

[14] Sadewa, G. P. (2019). Membongkar Identitas Dalam Film “Wandu.” Rekam Jurnal Fotografi, Televisi, Dan Animasi.

[15] Sobur, A. (2017). Semiotika Komunikasi. Remaja Karya.

[16] Sobur, Alex. (2006). Analisis Teks Media. PT. Remaja Rosdakarya.

[17] Suprihono, A. E. (2019). Sinematografi Wayang: Persoalan Transmedia Seni Pertunjukan Tradisional Dalam Program Tayangan Televisi, Rekam Jurnal Fotografi, Televisi, dan Animasi.

[18] Tinarbuko, S. (2008). Semiotika Komunikasi Visual. Jalasutra.

[19] Wenerda, I. (2020). Proses Komunikasi pada Pengguna Aplikasi Whatsapp yang Menonaktifkan Fitur Read Receipts. Channel Jurnal Komunikasi.

[20] Whitehead, J. (2002). Creating Interior Atmosphere: Mise-en-scène and Interior Design. Bloomsbury Publishing.

[21] Wibowo, A. A. (2019). Kajian Konsep Tanda Hipersemiotika Pada Iklan Kecap Bango Seri Eat Locally. Citra Dirga : Jurnal Desain Komunikasi Visual Dan Intermedia.

[22] Wibowo, A. A., \& Ayu, D. D. F. (2020). Analisis Ikonologi Iklan Billboard GO-PAY di Yogyakarta. Citra Dirga : Jurnal Desain Komunikasi Visual Dan Intermedia. 
